\title{
Impact of Visual Instructions on Oral Health Status of Children with Sensory Impairment in Western Maharashtra
}

\author{
Christina Sarah James ${ }^{1}$, K. M. Shivakumar ${ }^{2}$
}

\begin{abstract}
${ }_{1}^{1}$ Department of Public Health Dentistry, School of Dental Sciences, Krishna Institute of Medical Sciences (Deemed to be University), Karad, Maharashtra, India. ${ }^{2}$ Department of Public Health Dentistry, School of Dental Sciences, Krishna Institute of Medical Sciences (Deemed to be University), Karad, Maharashtra, India.
\end{abstract}

\section{ABSTRACT}

\section{BACKGROUND}

Oral health status of individuals with special needs is considered to be an important part of the overall health scenario. In India, people with disability may be with one or more kind of disability and is equal to $2.1 \%$ of the population. This study focuses on the Impact of visual instructions on oral health status of children with sensory impairment in western Maharashtra.

\section{METHODS}

An interventional study was conducted among 90 children with either one or both of the following sensory disabilities such as deafness or mute at the Mukh Badhir School, Gajanan Society, Karad, and Maharashtra. WHO oral assessment form 1997 was used to assess oral health status and treatment needs of children, plaque level, calculus level and dental caries assessment.

\section{RESULTS}

Females $(0.64 \pm 0.29)$ showed higher score when the mean of plaque and gingival index was considered in both the control and experimental group, prior and post the intervention. The results obtained were not statistically significant.

\section{CONCLUSIONS}

Oral hygiene maintenance is a serious issue in case of sensory impaired children. Even with incorporation of Disclosing Agent appreciable changes were not noted in the study groups post intervention.

\section{KEY WORDS}

Sensory Impaired, Disclosing Agent
Corresponding Author:

Dr. K. M. Shivakumar

Professor and Head,

Department of Public Health Dentistry,

School of Dental Sciences,

Krishna Institute of Medical Sciences,

(Deemed to be University), Karad-415110,

Maharashtra, India.

E-mail: shivakumarkm1@gmail.com

DOI: $10.14260 / \mathrm{jemds} / 2019 / 752$

Financial or Other Competing Interests: None.

How to Cite This Article:

James CS, Shivakumar KM. Impact of visual instructions on oral health status of children with sensory impairment in Western Maharashtra. J. Evolution Med. Dent. Sci. 2019;8(46):3474-3478, DOI: 10.14260/jemds/2019/752

Submission 19-09-2019, Peer Review 02-11-2019, Acceptance 08-11-2019, Published 18-11-2019.

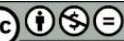




\section{BACKGROUND}

When compared to adults, oral health is an important aspect of health in children, in particular it is more of a concern in children with special needs. The American health association defines child with disability as a "child who for various reasons cannot fully make use of all his or her physical, mental and social abilities".[1] Individuals with special needs are more prone to dental caries. Dental treatment is an unattended need of the disabled. The identified cause of periodontal disease and dental caries is considered to be an accumulation of plaque in differently able children. Increased accumulation of plaque is due to inefficient oral cleansing practices.

Disability of any kind can hamper the effective maintenance of oral hygiene. People with disabilities have to be provided with equal opportunities for oral health and hygiene as any other individual. Oral health plays an important role in the aesthetic and communication abilities. It also affects and dominates a major part in the biological, psychological and social outlook of an individual.

According to WHO estimates, individuals with disability comprise $10 \%$ of the population in developed countries and $12 \%$ in developing countries.[2] Census of year 2011 has revealed that over 26.8 million people in India as suffering from one or the other kind of disability. Among the total disabled in the country i.e. 26.8 million- 15 million are males and 11.8 million females. According to the census, $20.3 \%$ of the disabled are physically challenged followed by hearing impaired (18.9\%) and visually impaired (18.8\%). Nearly $5.6 \%$ of the disabled is in intellectually disabled group. ${ }^{[3]}$ Studies performed by Anaise in Israel, Shaw et al in UK and Purohit et al in South India found poor oral health attributes among special care children.[4,5,6] Shaw et al. in 1986 and Rao et al. in 2005 reported poor oral hygiene status among special care children. ${ }^{[5,6]}$ A study report of Purohit et al in 2010 in South India showed a dental caries prevalence of $89.1 \%$ in special care children. They had higher DMFT and deft than their healthy counterparts. ${ }^{[7]}$

These study reports clearly indicates that children with disabilities are considered to be an unnoticed group of human society with high unmet needs which required special attention. The maintenance of oral health condition of differently abled children is a great challenge to the dental public health. For more systematic and comprehensive planning of dental health program for differently abled children a detailed report of the oral health status of children with special needs should be collected.

Keeping the above details in mind, for a better evaluation of oral health status an interventional study was designed using the WHO assessment form 1997[8] which provided access to the oral health status and treatment needs of children, plaque level, calculus level, and dental caries assessment of children with special needs in the age range of 5-18 years attending special school in Western Maharashtra.

\section{METHODS}

An interventional study was conducted at the Mukh Badhir School, Gajanan Society, Karad. The number of subjects for this particular study was 90 after the final sample size calculation. The inclusion criteria for the study were a) Children with either one or both of the following sensory disabilities such as deafness or mute b) Children between the age group of 5-18 years of age. The exclusion criteria included children with other systemic and mental disabilities. Ethical clearance was obtained from the ethical research committee of Krishna Institute of Medical Sciences Deemed to be University, Karad. Permission was taken from the respective authorities of the school prior to the clinical examination. Informed consent was obtained from the parent/ guardians.

With the start of the study a questionnaire was given to the parent/guardians/teachers which included questions which would help to evaluate the knowledge regarding the oral health maintenance of the subjects. It included information pertaining to study like the subject's name, gender and age. It had questions assessing the oral health practices, requirement of assistance to carry out oral hygiene and also awareness about the oral health issues.

Type 3 clinical examination which includes mainly of Diagnostic instruments such as mouth mirror and explorer, adequate illumination was conducted, was conducted, World Health Organization (WHO) assessment form (8) was used to assess the oral health status and treatment needs of the subjects. Dental clinical examination took place at the school in the classroom with participants seated on the ordinary chair and illumination provided by the natural light. Other armamentarium used were mouth mirrors, straight probes and kidney trays and GC Tri Plaque ID Gel. The subjects for the study (90) were divided into two groups. One set was control group (45) and the other one was the interventional group (45). The study was conducted in two groups for the effective comparative study. The interventional group along with the teachers and caregivers were taught brushing technique (Modified bass technique) which was accompanied by the inclusion of disclosing agent (GC Tri Plaque ID Gel). Disclosing agent helped in the proper identification of the areas with the presence of plaque and which in turn helped in the effective cleaning of the teeth. The control group was taught the brushing technique alone without the inclusion of disclosing agent. The interventional group was asked to carry out the proper brushing of the areas highlighted by the disclosing agents as areas with more plaque accumulation and maintaining healthy oral hygiene practice.

After a period of 3 months both the groups were evaluated, and the post interventional findings were recorded in the screening Performa to evaluate the improvement and for the better comparison between the study groups. After the study, both the groups were assembled and were given proper demonstration on brushing techniques with inclusion of disclosing agents. General awareness about the oral health diseases and the importance of maintaining oral hygiene was given. The data was tabulated in MS- excel using serial number for each subject in the study groups and statistical analysis was done. Statistical analysis was done using the SPSS 20.0 IBM software (Statistical package for the social sciences). Data collected were analysed using the chi-square test to find association between the oral hygiene situation and about oral health practices and un-paired t-test was used to find the differences between control and experimental group providing oral health instructions. 


\section{RESULTS}

Table 1 shows gender wise response of the study population about the knowledge-based response of the students and caregivers included in the study population. Out of the study population $51 \%$ of the students never visited the dentist whereas $49 \%$ visited the dentist once in 6 months or year. The reason for the visit to the dentist was due to call from the dentist or due to pain or routine check-up by $61 \%$ of the population and 39\% dint know the reason for their visit to the dentist. $92 \%$ of the study population brushed teeth independently and $86 \%$ dint follow any special techniques of tooth brushing. $86 \%$ of the caregivers of the students agreed on tooth brushing skills to be specially trained to the students. Training in the natural environment should be given to the students were agreed by $76 \%$ of the caregivers. $78 \%$ of the study group was unaware about the different brushing techniques. Routine brushing of the teeth was done only once by $59 \%$ of the students. $57 \%$ among the study population complained about problems relation to oral health. $78 \%$ of the caregivers gave positive respond when asked about the knowledge and information imparted to students on oral hygiene. $62 \%$ of the caregivers were unaware about the different oral health abnormalities. Assistance of the caregivers during brushing was a requirement by $53 \%$ of the study population.

\begin{tabular}{|c|c|c|c|c|c|c|}
\hline \multirow[b]{2}{*}{ Questions } & \multirow[b]{2}{*}{$\begin{array}{l}\text { Res- } \\
\text { ponse }\end{array}$} & \multicolumn{2}{|c|}{ Sex } & \multirow[b]{2}{*}{$\begin{array}{l}\text { Total } \\
\mathrm{N}=90\end{array}$} & \multirow{2}{*}{$\begin{array}{c}\text { Chi- } \\
\text { Squ- } \\
\text { are }\end{array}$} & \multirow[b]{2}{*}{$\mathbf{p}$} \\
\hline & & $\begin{array}{l}\text { Males } \\
\mathrm{N}=59\end{array}$ & $\begin{array}{c}\text { Females } \\
\mathrm{N}=31\end{array}$ & & & \\
\hline \multirow{3}{*}{ 1. How often do you visit the dentist? } & $\begin{array}{l}\text { Once in } 6 \\
\text { months }\end{array}$ & $14(24 \%)$ & $3(10 \%)$ & $17(19 \%)$ & \multirow{4}{*}{3.322} & \multirow{4}{*}{$0.1 \mathrm{c}$} \\
\hline & $\begin{array}{c}\text { Oncein a } \\
\text { Year }\end{array}$ & $15(25 \%)$ & $12(39 \%)$ & $27(30 \%)$ & & \\
\hline & $\begin{array}{l}\text { Never } \\
\text { Visited }\end{array}$ & $30(51 \%)$ & $16(51 \%)$ & $46(51 \%)$ & & \\
\hline \multirow{4}{*}{ 2. Reason to Visit Last Time? } & $\begin{array}{l}\text { Routine } \\
\text { Check-up }\end{array}$ & $7(12 \%)$ & $3(10 \%)$ & $10(11 \%)$ & & \\
\hline & Pain & $19(32 \%)$ & $10(32 \%)$ & $29(32 \%)$ & \multirow{3}{*}{0.273} & \multirow{3}{*}{0.97} \\
\hline & $\begin{array}{r}\text { Was called } \\
\text { by dentist }\end{array}$ & $11(19 \%)$ & $5(16 \%)$ & $16(18 \%)$ & & \\
\hline & $\begin{array}{c}\text { Don't } \\
\text { Know } \\
\end{array}$ & $22(37 \%)$ & $13(42 \%)$ & $35(39 \%)$ & & \\
\hline \multirow{2}{*}{$\begin{array}{l}\text { 3. Does Your Child Brush Teeth } \\
\text { Independently? }\end{array}$} & Yes & $53(89 \%)$ & $30(97 \%)$ & $83(92 \%)$ & \multirow{2}{*}{0.57} & \multirow{2}{*}{0.45} \\
\hline & No & $6(11 \%)$ & $1(3 \%)$ & $7(8 \%)$ & & \\
\hline \multirow{2}{*}{$\begin{array}{l}\text { 4. Did you use any special method to } \\
\text { train your child about tooth brushing? }\end{array}$} & Yes & $10(17 \%)$ & $3(10 \%)$ & $13(14 \%)$ & \multirow{2}{*}{0.38} & \multirow{2}{*}{0.54} \\
\hline & No & $49(83 \%)$ & $28(90 \%)$ & $77(86 \%)$ & & \\
\hline \multirow{2}{*}{$\begin{array}{l}\text { 5. Is itimportant for your child to have } \\
\text { tooth brushing skillsspecially trained? }\end{array}$} & Yes & $47(80 \%)$ & $25(81 \%)$ & $72(80 \%)$ & \multirow{2}{*}{0.01} & \multirow{2}{*}{0.91} \\
\hline & No & $12(20 \%)$ & $6(19 \%)$ & $18(20 \%)$ & & \\
\hline \multirow{2}{*}{$\begin{array}{l}\text { 6. Is it important for your child to use } \\
\text { learned skills in hisor her natural } \\
\text { environment? }\end{array}$} & Yes & $45(76 \%)$ & $23(74 \%)$ & $68(76 \%)$ & \multirow[b]{2}{*}{0.05} & \multirow[b]{2}{*}{0.83} \\
\hline & No & $14(24 \%)$ & $8(26 \%)$ & $22(24 \%)$ & & \\
\hline \multirow{2}{*}{$\begin{array}{l}\text { 7. Doyou know different methodsfor } \\
\text { tooth brushing? }\end{array}$} & Yes & $14(24 \%)$ & $6(19 \%)$ & $20(22 \%)$ & \multirow{2}{*}{0.04} & \multirow{2}{*}{0.84} \\
\hline & No & $45(76 \%)$ & $25(81 \%)$ & $70(78 \%)$ & & \\
\hline \multirow{2}{*}{$\begin{array}{l}\text { 8. How often does your child brush his } \\
\text { or her teeth in a day? }\end{array}$} & Once & $32(54 \%)$ & $21(68 \%)$ & $53(59 \%)$ & \multirow{2}{*}{1.02} & \multirow{2}{*}{0.31} \\
\hline & Twice & $27(46 \%)$ & $10(32 \%)$ & $37(41 \%)$ & & \\
\hline \multirow{2}{*}{$\begin{array}{l}\text { 9. Does your child complain of any oral } \\
\text { health problems often? }\end{array}$} & Yes & $32(54 \%)$ & $19(61 \%)$ & $51(57 \%)$ & 0.17 & 0.68 \\
\hline & No & $27(46 \%)$ & $12(39 \%)$ & $39(43 \%)$ & 0.17 & 0.00 \\
\hline 10. Do the child's teacher/caregivers & Yes & $43(73 \%)$ & $27(87 \%)$ & $70(78 \%)$ & 163 & 02 \\
\hline teach the child aboutoral hygiene? & No & $16(27 \%)$ & $4(13 \%)$ & $20(22 \%)$ & 1.03 & 0.2 \\
\hline 11.Are you aware different oral & Yes & $23(39 \%)$ & $11(35 \%)$ & $34(38 \%)$ & 0.009 & 0.92 \\
\hline abnormalities? & No & $36(61 \%)$ & $20(65 \%)$ & $56(62 \%)$ & & \\
\hline $\begin{array}{l}\text { 12. Does your child need your } \\
\text { caretaker's assessment during } \\
\text { brushing? }\end{array}$ & Yes & $32(54 \%)$ & $16(52 \%)$ & $48(53 \%)$ & 0.0002 & 0.99 \\
\hline & No & $27(46 \%)$ & $15(48 \%)$ & $42(47 \%)$ & & \\
\hline nder_Wlice & sociat & n of Kne & $\begin{array}{l}\text { owledge } \\
\text { ces }\end{array}$ & 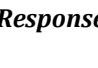 & & \\
\hline
\end{tabular}

Table 2(a) and 2(b) shows gender wise distribution of the study variables in the control and experimental group respectively with regard to plaque and gingival index. No statistical significance was seen with results as $p>0.05$. Table $3(\mathrm{a})$ and 3(b) shows age wise distribution of the study variables in the control and experimental groups respectively. The results showed statistical significance in post-PI of the control group which has $p$ value as 0.01 and pre-PI of the experimental group $p$ value as 0.02 which is less than 0.05 .

\begin{tabular}{|c|c|c|c|c|c|c|c|}
\hline \multicolumn{2}{|c|}{$\begin{array}{c}\text { Control Group Study } \\
\text { Variables }\end{array}$} & \multirow{2}{*}{\begin{tabular}{c|}
$\mathbf{N}=\mathbf{4 5}$ \\
28
\end{tabular}} & \multirow{2}{*}{$\begin{array}{c}\text { Mean } \\
0.35\end{array}$} & \multirow{2}{*}{$\begin{array}{l}\text { S.D. } \\
0.19\end{array}$} & \multirow{2}{*}{$\begin{array}{c}\text { Std. } \\
\text { Error } \\
\text { Mean } \\
0.03 \\
\end{array}$} & \multirow{3}{*}{$\frac{\text { t-Value }}{1.09}$} & \multirow{3}{*}{$\begin{array}{c}\mathbf{p} \\
0.28\end{array}$} \\
\hline \multirow{2}{*}{$\begin{array}{c}\text { Pre- } \\
\text { PI }\end{array}$} & Males & & & & & & \\
\hline & Females & 17 & 0.60 & 1.15 & 0.28 & & \\
\hline \multirow{2}{*}{ Post-PI } & Males & 28 & 0.47 & 0.57 & 0.10 & \multirow{2}{*}{0.50} & \multirow{2}{*}{0.62} \\
\hline & Females & 17 & 0.40 & 0.25 & 0.06 & & \\
\hline \multirow{2}{*}{$\begin{array}{c}\text { Pre- } \\
\text { GI } \\
\end{array}$} & Males & 28 & 0.32 & 0.50 & 0.09 & \multirow{2}{*}{0.95} & \multirow{2}{*}{0.34} \\
\hline & Females & 17 & 0.20 & 0.24 & 0.06 & & \\
\hline \multirow{2}{*}{ Post-GI } & Males & 28 & 0.26 & 0.25 & 0.04 & \multirow{2}{*}{1.42} & \multirow{2}{*}{0.16} \\
\hline & Females & 17 & 0.37 & 0.25 & 0.06 & & \\
\hline & a (a) & er $И$ & Dic & utid & Stud & iable & \\
\hline
\end{tabular}

\begin{tabular}{|c|c|c|c|c|c|c|c|}
\hline \multicolumn{2}{|c|}{$\begin{array}{c}\text { Experimental } \\
\text { Group Study } \\
\text { Variables }\end{array}$} & \multirow{2}{*}{$\begin{array}{c}N=45 \\
31\end{array}$} & \multirow{2}{*}{$\begin{array}{c}\text { Mean } \\
0.49\end{array}$} & \multirow{2}{*}{$\begin{array}{l}\text { S.D. } \\
0.37\end{array}$} & \multirow{2}{*}{$\begin{array}{c}\text { Std. } \\
\text { Error } \\
\text { Mean }\end{array}$} & \multirow{3}{*}{\begin{tabular}{|c}
$\begin{array}{c}\mathbf{t}- \\
\text { Value }\end{array}$ \\
1.33
\end{tabular}} & \multirow{3}{*}{$\begin{array}{c}\mathbf{p} \\
0.18\end{array}$} \\
\hline Pre-PI & Males & & & & & & \\
\hline Pre-r1 & Females & 14 & 0.64 & 0.29 & 0.07 & & \\
\hline \multirow{2}{*}{ post-PI } & Males & 31 & 0.32 & 0.21 & 0.03 & \multirow{2}{*}{1.63} & \multirow{2}{*}{0.12} \\
\hline & Females & 14 & 0.45 & 0.26 & 0.07 & & \\
\hline \multirow{2}{*}{ Pre-GI } & Males & 31 & 0.39 & 0.37 & 0.06 & \multirow{2}{*}{0.2} & \multirow{2}{*}{0.84} \\
\hline & Females & 14 & 0.37 & 0.42 & 0.11 & & \\
\hline \multirow{2}{*}{ Post-GI } & Males & 31 & 0.30 & 0.20 & 0.03 & \multirow{2}{*}{0.08} & \multirow{2}{*}{0.93} \\
\hline & Females & 14 & 0.30 & 0.38 & 0.10 & & \\
\hline
\end{tabular}

Table 2(b). Gender Wise Distribution of Study Variables in the Experimental Group

\begin{tabular}{|c|c|c|c|c|c|c|c|}
\hline \multicolumn{2}{|c|}{$\begin{array}{c}\text { Control Group Study } \\
\text { Variables }\end{array}$} & \multirow{2}{*}{$\begin{array}{c}\mathbf{N}=\mathbf{4 5} \\
19\end{array}$} & \multirow{2}{*}{\begin{tabular}{|c|} 
Mean \\
0.30
\end{tabular}} & \multirow{2}{*}{$\begin{array}{l}\text { S.D. } \\
0.25\end{array}$} & \multirow{2}{*}{$\begin{array}{c}\begin{array}{c}\text { Std. Error } \\
\text { Mean }\end{array} \\
0.05 \\
\end{array}$} & \multirow{3}{*}{\begin{tabular}{|c|}
$\begin{array}{c}\text { t- } \\
\text { Value }\end{array}$ \\
\cline { 1 - 2 } 1.14
\end{tabular}} & \multirow{3}{*}{$\begin{array}{c}\mathbf{p} \\
0.26\end{array}$} \\
\hline ProPI & $<=10.00$ & & & & & & \\
\hline Pre-PI & $11.00-20.00$ & 26 & 0.55 & 0.92 & 0.18 & & \\
\hline \multirow{2}{*}{ Post-PI } & $<=10.00$ & 19 & 0.64 & 0.67 & 0.15 & \multirow{2}{*}{2.55} & \multirow{2}{*}{$0.01 *$} \\
\hline & $11.00-20.00$ & 26 & 0.30 & 0.16 & 0.03 & & \\
\hline \multirow{2}{*}{ Pre-GI } & $<=10.00$ & 19 & 0.30 & 0.41 & 0.09 & \multirow{2}{*}{0.29} & \multirow{2}{*}{0.76} \\
\hline & $11.00-20.00$ & 26 & 0.26 & 0.43 & 0.08 & & \\
\hline \multirow{2}{*}{ Post-GI } & $<=10.00$ & 19 & 0.38 & 0.33 & 0.07 & \multirow{2}{*}{1.88} & \multirow{2}{*}{0.06} \\
\hline & 11.0020 .00 & 26 & 0.24 & 0.17 & 0.03 & & \\
\hline
\end{tabular}

\begin{tabular}{|c|c|c|c|c|c|c|c|}
\hline \multicolumn{2}{|c|}{$\begin{array}{c}\text { Experimental Group } \\
\text { Study Variables } \\
\end{array}$} & \multirow{3}{*}{$\begin{array}{c}\mathrm{N}=\mathbf{4 5} \\
19 \\
\end{array}$} & \multirow{2}{*}{$\begin{array}{c}\text { Mean } \\
0.67 \\
\end{array}$} & \multirow{2}{*}{$\begin{array}{l}\text { S.D. } \\
0.44 \\
\end{array}$} & \multirow{3}{*}{\begin{tabular}{c|}
$\begin{array}{c}\text { Std. Error } \\
\text { Mean }\end{array}$ \\
0.10 \\
0.04
\end{tabular}} & \multirow{3}{*}{\begin{tabular}{c|}
$\begin{array}{c}\text { t- } \\
\text { Value }\end{array}$ \\
2.37
\end{tabular}} & \\
\hline \multirow{2}{*}{ Pre-PI } & $<=10.00$ & & & & & & \\
\hline & $11.00-20.00$ & & 0.43 & 0.24 & & & \\
\hline \multirow{2}{*}{ Post-PI } & $<=10.00$ & 19 & 0.43 & 0.30 & 0.06 & \multirow{2}{*}{1.75} & \multirow{2}{*}{0.08} \\
\hline & $11.00-20.00$ & 26 & 0.31 & 0.15 & 03 & & \\
\hline \multirow{2}{*}{ Pre-GI } & $<=10.00$ & 19 & 0.48 & 0.45 & 10 & \multirow{2}{*}{1.42} & \multirow{2}{*}{0.16} \\
\hline & $11.00-20.00$ & 26 & 0.31 & 0.32 & 06 & & \\
\hline \multirow{2}{*}{ Post-GI } & $<=10.00$ & 19 & 0.38 & 0.28 & 0.06 & \multirow{2}{*}{1.94} & \multirow{2}{*}{0.05} \\
\hline & $11.00-20.00$ & 26 & 0.23 & 0.23 & \begin{tabular}{l|}
0.04 \\
\end{tabular} & & \\
\hline \multicolumn{8}{|c|}{$\begin{array}{c}\text { Table 3(b). Age Wise Distribution of Study Variables in the } \\
\text { Experimental Group }\end{array}$} \\
\hline
\end{tabular}

\section{DISCUSSION}

Oral disease represents a major health problem among individuals with disabilities. ${ }^{[9,10,11,12]}$ The prevalence and severity of oral diseases of this group are comparatively higher than the general population.[13] Poor periodontal health and oral cleanliness are noted in children with disabilities.[14,15] In our study the brushing technique was accompanied with the inclusion of a disclosing agent (GC TriPlaque ID Gel). The property of this gel enables in proper differentiation of the plaque into old plaque, new plaque and extra high-risk plaque. This gel offered specific colour to the 3 types of plaque that is, pink/ red to new plaque, blue/purple 
colour to the old plaque and light blue colour to extra highrisk plaque. This method facilitated the brushing technique carried out by the sensory impaired by visual enhancement.

The deaf and mute children require greater attention compared to the other population. These children face difficulty in comprehending instructions and following it in the way it is required to be carried out. To deliver quality health education, different approaches can be planned to convey instructions efficiently. The folks of the children with sensory impairment also require basic knowledge on both medical and dental management of their wards. Training on oral hygiene practices should be given on daily basis to achieve desired benefits of the technique demonstrated to them in the study. When an educational intervention among hearing impaired children was carried out in a study conducted by Alse et al.[16] it showed higher plaque score before oral health education in children with hearing impairment, similar to earlier studies.[17-21]

In the present study, the females showed higher score when the mean of plaque and gingival index was considered in both control and experimental group, prior and post intervention. This may be due to inability to understand or respond to the instructions given and also due to lack of monitoring from the parents or caretakers. In a study conducted by Shivakumar et al, the mean Loe and Silness PI score was $0.79 \pm 1.32$. The mean Loe and Silness PI score among the male deaf and mute children was found to be $0.89 \pm 1.55$, and that among the female deaf and mute children was $0.67 \pm 1.23$. However, there were no statistically significant differences has been observed among the study population.[22] The results were in consistent with the studies conducted by Rawlani et al [23] which was different from the results obtained in our study.

The children in the study those below 10 years showed higher score when the mean of plaque and gingival index was in both control and experimental group, prior and post intervention. When a study was conducted in hearing and speech impaired children in Ahmedabad city, the mean GI of children below 10 years of age was shown to be $0.62 \pm 0.27$ and that of children between 10-12 years of age showed mean GI of $0.74 \pm 0.2 .{ }^{[24]}$ The higher levels of dental disease in these handicapped people seem to be due to poor use of dental services as well as oral health education is necessary to ensure that optimum dental health is within the reach of these less fortunate children.[25] It is obvious that many disabled individuals will find the maintenance of their own oral hygiene much more difficult than normal individuals because those with hearing impairment cannot understand and respond to the instructions given.[19] Studies have shown that oral hygiene can be improved significantly by providing intensified daily brushing by dental personnel, by the development of self-help workshops, by providing effective staff training or by a combination of all approaches. ${ }^{[5]}$

\section{CONCLUSIONS}

There is a need for enhancement of oral hygiene management among the sensory impaired children with incorporation of Disclosing Agent. But this approach would be successful only with continued and persistent efforts from children and their parents or caregivers.

\section{REFERENCES}

[1] Doshi JJ, Patel UK, Krishnan V, et al. Dental cleanliness in handicapped, blinds and the role of dentist. Journal of Indian Dental Association 1981;53:179-82.

[2] Baykan Z. Causes and prevention of disabilities, handicaps and defects. J Cont Med Educ 2003;9:336-8.

[3] Census of India 2011. Data on Disability. http://www.censusindia.gov.in.

[4] Anaise JZ. Periodontal disease and oral hygiene in a group of blind and sighted Israeli teenagers 14-17 years of age. Community Dent Oral Epidemiol 1979;7(6):3536.

[5] Shaw L, Maclaurin ET, Foster TD. Dental study of handicapped children attending special schools in Birmingham, UK. Community Dent Oral Epidemiol 1986;14(1):24-7.

[6] Rao D, Amitha H, Munshi AK. Oral hygiene status of disabled children and adolescents attending special schools of South Canara, India. Hong Kong Dent J 2005;2(2):107-13.

[7] Purohit BM, Acharya S, Bhat M. Oral health status and treatment needs of children attending special schools in South India: a comparative study. Spec Care Dentist 2010;30(6):235-41.

[8] World Health Organization. Oral health surveys - basic methods. 4th edn. Geneva: WHO, 1997.

[9] Aytac S. Increasing importance of rehabilitation of the disabled child. J Dokuz Eyliil Univ Soc Sci 2000;2(2):2135.

[10] Beange HP. Caring for a vulnerable population: who will take responsibility for those getting a raw deal from the health care system? Med J Aust 1996;164(3):159-60.

[11] Scott A, March L, Stokes ML. A surgery of oral health in a population of adults with developmental disabilities: comparison with a national oral health survey of the general population. Aust Dent J 1998;43(4):257-61.

[12] Faulks D, Hennequin M. Evaluation of a long-term oral health program of carers of children and adults with intellectual disabilities. Spec Care Dentist 2000;20(5):119-208.

[13] Jurek GH, Reid WH. Oral health of institutionalized individuals with mental retardation. Am J Ment Retard 1994;98(5):656-60.

[14] Shyama M, Al-Mutawa SA, Morris RE, et al. Dental caries experience of disabled children and young adults in Kuwait. Community Dent Health 2001;18(3):181-6.

[15] Van Houtem CM, De Jongh A, Broers DL, et al. Postacademic specialties 9. Dental care of disabled children living at home. Ned Tijdschr Tandheelkd 2007;114(3):129-33.

[16] Alse ASS, Anandkrishna L, Chandra P, et al. Educational intervention on the plaque score among the hearing impaired children. Journal of Advanced Clinical and Research Insights 2015;2:26-30. 
[17] Alsmark SSB, García J, Martínez MR, et al. How to improve communication with deaf children in the dental clinic. Med Oral Patol Oral Cir Bucal 2007;12(8):E57681.

[18] Champion J, Holt R. Dental care for children and young people who have a hearing impairment. Br Dent J 2000;189(3):155-9.

[19] Jain M, Bharadwaj SP, Kaira LS, et al. Oral health status and treatment need among institutionalized hearingimpaired and blind children and young adults in Udaipur, India. A comparative study. J Oral Health Dent Manage 2013;12(1):41-9.

[20] Brown JP, Schodel DR. A review of controlled surveys of dental disease in handicapped persons. ASDC J Dent Child 1976;43(5):313-20.

[21] Kumar S, Dagli RJ, Mathur A, et al. Oral hygiene status in relation to socio-demographic factors of children and adults who are hearing impaired, attending a special school. Spec Care Dentist 2008;28(6):258-64.
[22] Shivakumar KM, Patil S, Kadashetti V. Oral health status and dental treatment needs of sensory-impaired children of Satara District, India. J Int Oral Health 2017;9(5):197-201.

[23] Rawlani S, Rawlani S, Motwani M, et al. Oral Health status of deaf and mute children attending special school in Anand-Wan, Warora, India. J Korean Dent Sci 2010;3(2):20-5.

[24] Choudhari SR, Solanki PJ, Goyal SP, et al. The prevalence of dental caries and gingival diseases in institutionalized special children of 6-12 years of age in Ahmedabad City, Gujarat, India. Int $\mathrm{J}$ of Oral Health and Med Res 2017;4(3):31-4.

[25] Vignesha H, Soh G, Lo GL, et al. Dental health of disabled children in Singapore. Australian Dental Journal 1991;36(2):151-6. 